\title{
PLANOWANIE OPIEKI PIELĘGNIARSKIEJ NAD URODZONYM PRZEDWCZEŚNIE NOWORODKIEM ZZABURZENIAMI ODDYCHANIA, WENTYLOWANYM MECHANICZNIE. STUDIUM PRZYPADKU
}

\author{
THE PLAN OF NURSING CARE OF BABIES BORN PREMATURELY WITH RESPIRATORY \\ DISORDERS, VENTILATED MECHANICALLY. CASE STUDY
}

Lucyna Sochocka, Edyta Kędra, Daria Bensz

Instytut Pielęgniarstwa

Państwowa Medyczna Wyższa Szkoła Zawodowa w Opolu

DOI: https://doi.org/10.20883/pielpol.2017.46

\section{STRESZCZENIE}

Założenia. Celem pracy jest zaprezentowanie przykładowego planu opieki pielęgniarskiej nad przedwcześnie urodzonym noworodkiem z zaburzeniami oddychania, wentylowanym mechanicznie. Proponowany plan opieki oparty został o klasyfikacje ICNP, będąca międzynarodowym standardem dla terminologii pielęgniarstwa, rekomendowanym przez ICN, a w Polsce przez PTP oraz Akredytowane Centrum Badania i Rozwoju ICNP ${ }^{\circledR}$. Klasyfikacja ta porządkuje terminologię specjalistyczną poprzez stworzenie słownika referencyjnego terminów wykorzystywanych do stawiania diagnozy pielęgniarskiej, planowania działań i oceniania wyników, którym przypisane są odpowiednie kody numeryczne. Dzięki temu staje się ona uniwersalnym narzędziem do porozumiewania się pielęgniarek na całym świecie i do zapewniania odpowiedniej jakości tej opieki.

Prezentacja przypadku. Noworodek L.O., „," A.A., urodzony w $25 \mathrm{Hbd}$ drogą cięcia cesarskiego, z masą urodzeniową 715 gram z ciąży I. Punktacja w skali Apgar w kolejnych minutach życia: 5 pkt. (w 1 min. życia), 6 pkt. (w 3, 5 i 10 min. życia). Leczony na oddziale patologii noworodka. W chwili przyjęcia stan dziecka ciężki, wcześniak skrajnie niedojrzały, zaintubowany, z objawami niewydolności oddechowej. Wymagał leczenia niewydolności oddechowej, zakażenia wrodzonego, zaburzeń żywieniowych, dysplazji oskrzelowo-płucnej, zaburzeń metabolicznych.

Wyniki. Profesjonalna opieka pielęgniarska nad noworodkiem przedwcześnie urodzonym ma bardzo duże znaczenie dla życia i dalszego rozwoju dziecka. Opiera się ona na obserwacji, monitorowaniu i pielęgnowaniu wcześniaka, a także na zachęcaniu rodziców do zaangażowania się w opiekę nad dzieckiem, co pozwala na budowanie trwałej więzi pomiędzy nimi. Zgodnie z obowiązującymi standardami opiera się na zindywidualizowanym procesie pielęgnowania, przygotowanym z wykorzystaniem klasyfikacji ICNP stanowiącej uniwersalny język komunikacji między personelem pielęgniarskim na całym świecie, pozwalającym na zapewnienie ciągłości opieki i wysokiej jej jakości.

SŁOWA KLUCZOWE: wcześniak, opieka pielęgniarska, klasyfikacja ICNP.

\section{ABSTRACT}

Aim. The aim of this paper is to present a model nursing care plan for prematurely born babies with respiratory disorders, ventilated mechanically. The presented care plan is based on the ICNP classification, an international standard for nursing terminology recommended by the ICN and in Poland by the PTP and the ICNP ${ }^{\circledR}$ Accredited Research and Development Center. This classification categorizes specialist terminology by creating a reference dictionary of terms used to diagnose nursing, planning activities, and evaluating results to which appropriate numerical codes are assigned. This makes it a universal tool for communicating with nurses around the world and providing quality care.

Case presentation. A newborn L.O, 'c' A.A, born in $25 \mathrm{Hbd}$, by caesarean section with birth weight 715 grams from pregnancy I. The Apgar score in subsequent minutes of life: 5 points. (in 1 minute of life), 6 points (in 3, 5 and 10 min. of life) on the neonatal pathology ward. At the time of adoption the baby's condition was severe, he was extremely immature, intubated with symptoms of respiratory failure. The baby required treatment for respiratory failure, congenital infection, nutritional disorders, bronchopulmonary dysplasia and metabolic disorders.

Results. Professional nursing care for a premature newborn baby is very important for his/her life and development. It is based on the observation, monitoring and care of premature babies, as well as encouraging parents to become involved in the care of their baby, thus building a lasting bond between them. According to current standards, it is based on a personalized nursing process prepared using the ICNP classification, which is the universal language of communication between nursing staff around the world, allowing for continuity of care and high quality.

KEYWORDS: premature, nursing care, ICNP classification. 


\section{Wprowadzenie}

W Polsce od kilku lat odsetek przedwczesnych porodów utrzymuje się na poziomie $6,5 \%$ wszystkich porodów. Co roku na świat przychodzi od 3500 do 4000 dzieci z bardzo małą masą urodzeniową. Przeżywalność wcześniaków ważących 750-1000 gram wynosi ponad 90\%, dla noworodków z masą 500-750 gram - 50-75\%, a dla ważących do 500 gram tylko 1-5\% [1, 2]. Noworodek urodzony przedwcześnie musi zmagać się z wieloma problemami wynikającymi z niedojrzałości jego organizmu. Na uwagę zasługują m.in.: brak zdolności samodzielnego oddychania, bezdechy (którym może towarzyszyć bradykardia), zaburzone ssanie, trawienie pokarmów, opróżnianie żołądka, hipotermia, późne zamknięcie przewodu tętniczego Botalla, zaburzenia metaboliczne [3, 4]. Rodzaj oraz stopień zaburzeń oddychania uzależniony jest od tygodnia ciąży, w którym nastąpiło przerwanie rozwoju układu oddechowego płodu. Ich profilaktyka polega na podaży glikokortykosteroidów w czasie od 7 do 10 dni poprzedzających poród, w sytuacji gdy istnieje podejrzenie wystąpienia przedwczesnego porodu. Podanie steroidów ma na celu przyspieszenie wytwarzania surfaktantu w płucach płodu, a także pozytywnie wpływa na układ nerwowy i serce dziecka [5, 6].

Do objawów klinicznych pojawiających się bezpośrednio po urodzeniu wcześniaka, wskazujących na zespół zaburzeń oddychania (ZZO), należą: nieregularne oddechy, bezdechy, widoczny wysiłek oddechowy z zaciąganiem przestrzeni międzyżebrowych, wzmożona praca skrzydełek nosa, stękanie wydechowe, osłabienie szmeru pęcherzykowego i oskrzelowego, trzeszczenia, obrzęk płuc, kończyn i tułowia, wzmagająca się sinica oraz hipoksemia, hiperkapnia i kwasica mieszana widoczne w badaniach laboratoryjnych $[3,7,8]$. Aby utrzymać przy życiu wcześniaka, który prezentuje typowe objawy zespołu zaburzeń oddychania, należy: uzupełnić niedobór surfaktantu (poprzez zaintubowanie pacjenta i zaaplikowanie dotchawiczo egzogennego surfaktantu do 2 godzin po urodzeniu), zapewnić prawidłowe utlenowanie przez zastosowanie wentylacji mechanicznej, podać płyny i kalorie, zapewnić środowisko cieplne, monitorować podstawowe parametry życiowe (częstość akcji serca, oddechów, ciśnienie tętnicze, saturację), kontrolować obraz radiologiczny płuc oraz wyrównać stan ogólny pacjenta [3, 6, 9].

Wraz z wprowadzeniem do praktycznego stosowania podaży surfaktantu metodą INSURE (Intubation Surfactant Extubation - polega na intubacji dziecka, podaży surfaktantu i natychmiastowej ekstubacji) czas stosowania wentylacji mechanicznej, która jest metodą inwazyjną, został skrócony do minimum [3, 9, 10]. Wybór odpowiedniej oraz efektywnej metody terapii oddechowej uzależniony jest od stanu klinicznego dziecka oraz wyników badań diagnostycznych. Obecnie rekomenduje się jak najkrótsze stosowanie wentylacji mechanicznej ze względu na towarzyszące jej powikłania (m.in. uszkodzenie miąższu płuc i rozwój dysplazji oskrzelowo-płucnej). Dąży się także do stosowania metod mniej inwazyjnych, które nie uszkadzają w takim stopniu płuc [11].

Celem pracy jest zaprezentowanie przykładowego planu opieki nad urodzonym przedwcześnie noworodkiem z zaburzeniami oddychania, wentylowanym mechanicznie, opracowanego z wykorzystaniem międzynarodowego standardu ICNP (Internatonal Classification Nursing Practice). Jest to klasyfikacja rekomendowana przez ICN, do praktycznego zastosowania w pielęgniarstwie światowym, oparta o ujednoliconą klasyfikację nazewnictwa wraz z przypisanymi im kodami dla poszczególnych etapów procesu pielęgnowania, (diagnozy pielęgniarskiej, działań, wyników).

W pracy wykorzystano metode indywidualnego przypadku, w której dominującą techniką była technika analizy dokumentacji, pozwalająca na przygotowanie opisu przypadku w oparciu o materiały zebrane na oddziale Patologii Noworodka w Centrum Ginekologii, Położnictwa i Neonatologii w Opolu, po wcześniejszym uzyskaniu zgody matki dziecka, dyrekcji szpitala oraz komisji bioetycznej. W ramach wiodącej metody zastosowano również technikę wywiadu, pozwalającą doprecyzować zebrane informacje na potrzeby przygotowywanego opisu. Równolegle skorzystano również z metody obserwacji $[12,13]$.

\section{Opis przypadku}

Noworodek L.O., „" A.A., urodzony w 25 Hbd drogą cięcia cesarskiego, z masą urodzeniową 715 gram z ciąży I. Wskazaniami do rozwiązania ciąży drogą cięcia cesarskiego były: stan zapalny pochwy (od 24 tygodnia ciąży), cechy zapalenia owodni (dodatnie markery stanu zapalnego w dniu porodu), poród przedwczesny (25 tydzień ciąży).

Matka dziecka - A.A., 30-letnia, rasy białej, regularnie korzystała z opieki prenatalnej; chorób ogólnoustrojowych nie odnotowano. Do szpitala trafiła z powodu nasilających się bólów podbrzusza. Przyczyną porodu przedwczesnego było zakażenie wstępujące, prowadzące do infekcji wewnątrzmacicznej. Na 7 godzin przed porodem matce dziecka podano $12 \mathrm{mg}$ Celestonu z powodu stanu zapalnego pochwy. Pacjentka nie posiadała wyniku testu GBS (na obecność paciorkowców z grupy B), dlatego też zastosowano profilaktykę śródporodową zakażenia GBS, podając 2 dawki Ampicyliny (pierwsza dawka 2 gramy, po 4 godzinach 1 gram). 
Do oceny stanu noworodka zastosowano skalę Apgar, w oparciu o którą punktacja w kolejnych minutach życia wynosiła: 5 pkt. (w 1 min. życia), 6 pkt. (w 3, 5 i $10 \mathrm{~min}$. życia). Bezpośrednio po urodzeniu wykonano u noworodka następujące zabiegi: okrycie folią Neowrap, odśluzowanie z górnych dróg oddechowych, masaż serca, intubację (rurka intubacyjna o wymiarach 2,0/8,5cm), podanie dotchawiczo 1 ampułki surfaktantu (Currosurf), wentylację oddechową Neopuff z $\mathrm{FiO}_{2} \mathrm{FiO}_{2}=0,25$. Dziecko zostało przewiezione z Bloku Operacyjnego na Oddział Patologii Noworodka za pomocą inkubatora transportowego; w tym czasie stosowano wentylację IMV z $\mathrm{FiO}_{2} \mathrm{FiO}_{2}=0,5$.

W chwili przyjęcia na oddział wcześniak był w stanie ciężkim, skrajnie niedojrzały, zaintubowany, z objawami niewydolności oddechowej. Klatka piersiowa była symetryczna, ustawiona wdechowo, osłuchowo słyszalne były rozsiane trzeszczenia nad polami płucnymi, obecny był szmer skurczowy u podstawy serca. Tętno było słabo wypełnione, stwierdzono zaburzenia perfuzji obwodowej. Wprowadzono kaniulę centralną przez żyłę pępowinową. Zastosowano płynoterapię, żywienie pozajelitowe, antybiotykoterapię empiryczną Ampicyliną i Biodacyną. Kontynuowano wentylację mechaniczną w systemie IMV, w pierwszej dobie życia bez zapotrzebowania na tlen. W badaniu USG jamy brzusznej nie stwierdzono żadnych nieprawidłowości. USG przezciemieniowe wykonane w dniu narodzin wykazało: krwawienie dokomorowe obustronne II stopnia, mózg wcześniaczy, bardzo niedojrzały, widoczną torbiel przegrody przezroczystej, wzmożoną echogeniczność tkanki okołokomorowej oraz brak cech patologii w dole tylnym czaszki.

Po podaży surfaktantu wykonano rtg klatki piersiowej, stwierdzające siateczkowo-ziarnisty rysunek płuc oraz zmniejszoną powietrzność miąższu. Końcówka rurki intubacyjnej położona nad rozwidleniem tchawicy. Obraz rtg przemawiał za Zespołem Zaburzeń Oddychania I stopnia. Sylwetka serca częściowo o zatartych rysach, wielkość serca prawidłowa. Na podstawie echokardiografii rozpoznano u noworodka drożny przewód tętniczy Botalla. Położenie serca, kurczliwość, połączenie żylno-przedsionkowe prawidłowe.

W trakcie hospitalizacji noworodek wymagał leczenia, między innymi niewydolności oddechowej w związku z niedojrzałością płuc i zakażeniem. Leczenie zaburzeń oddychania w kolejnych dobach życia wcześniaka wyglądało następująco:

- w 1-3 dobie życia stosowano oddech zastępczy w systemie IMV z maksymalną tlenoterapią 23\%,

- w3 dobie życia dziewczynka została ekstubowana, po czym zastosowano nieinwazyjne wsparcie oddechowe IF w trybie Biphasic; po ekstu- bacji między 3 a 5 dobą życia zapotrzebowanie na tlen wyglądało następująco: przez pierwszą godzinę zapotrzebowanie na tlen wynosiło $60 \%$, przez kolejne 12 godzin maksymalnie 40\%, w kolejnych dobach zapotrzebowanie wyniosło 35-25\%,

- $\quad$ w 5 dobie życia dziecko ekstubowano i prowadzono oddech wspomagany przy użyciu systemu Avea, z użyciem kaniuli nosowej wysokich przepływów (RAM) i maksymalną wartością $\mathrm{FiO}_{2} \mathrm{FiO}_{2} 28 \%$,

- w 8 dobie życia dziecko zostało powtórnie podłączone do systemu IF z maksymalną wartością $56-21 \%$,

- w 14 dobie życia, ze względu na pogorszenie się stanu dziecka, konieczna była intubacja i zastosowanie oddechu zastępczego w systemie IMV z podażą tlenu $23 \%$,

- od 16 do 37 doby życia noworodek podłączony był do systemu IF w trybie Biphasic, stężenie tlenu 56-21\%,

- w 37 dobie życia wcześniak został rozintubowany i podłączony do systemu IF nCPAP z maksymalną wartością 25-21\%, wprowadzono równocześnie ćwiczenia oddechowe,

- od 58 doby życia noworodek nie wymagał wsparcia oddechowego, okresowo stosowano tlenoterapię bierną z $\mathrm{FiO}_{2} \mathrm{FiO}_{2} 22 \%$.

W czasie stosowania tlenoterapii dziewczynka wymagała toalety drzewa oskrzelowego, odsysana była średnio 4 razy w ciągu doby. Z rurki intubacyjnej odsysano małą ilość śluzowo-żółtej, lepkiej wydzieliny. Z jamy ustnej i nosa odsysano większą ilość śluzowobiałej, gęstej wydzieliny.

Ze względu na zakażenie wrodzone w czasie pierwszych dni życia dziewczynce podawano dożylnie antybiotyki: Biodacynę (1 raz dziennie 12,5 mg, co 48 godzin przez okres $7 \mathrm{dni}$ ) oraz Ampicylinę (2 razy dziennie $70 \mathrm{mg}$ przez okres 9 dni). Z powodu potwierdzonych klinicznie i radiologicznie objawów progresji zmian zapalnych w płucach oraz zwiększonej ilości wydzieliny w drogach oddechowych (z wydzieliny tej wyhodowano pałeczkę ropy błękitnej Pseudomonas aeruginosa) oraz dodatniego wyniku posiewu końcówki kaniuli centralnej wprowadzono do leczenia Wankomycynę i Meronem. Wykluczono zakażenie atypowe oraz neuroinfekcję (na podstawie badania ogólnego i posiewu płynu mózgowo-rdzeniowego). W czasie antybiotykoterapii stosowano profilaktykę przeciwgrzybiczą (podając dziecku $4 \mathrm{mg}$ Flukonazolu co 48 godzin), którą zakończono w 23 dobie życia. Antybiotykoterapia została zakończona w 22 dobie życia. 
U noworodka zaobserwowano zaburzenia żywieniowe: zaleganie pokarmu w żołądku, wolny przyrost masy ciała, wzdęcie brzucha. Stosowano żywienie pozajelitowe do 17 doby życia, jednocześnie od 2 do 4 doby życia stosowano żywienie troficzne, od 5 doby życia systematycznie zwiększano dawki pokarmu matki podawane przez sondę żołądkową. Stosowano wzmacniacz mleka kobiecego HMF (1 saszetka na 50 ml mleka) oraz suplementy białka. Noworodek otrzymywał Esputicon (3 razy dziennie 1 kroplę) oraz Neonatusu LCR (1 raz dziennie 1 kapsułkę).

Z powodu dysplazji oskrzelowo-płucnej od 21 doby życia stosowano inhalacje z Pentoksyfiliny z dobrym efektem, a następnie podawano wziewnie steryd Pulmicort 2 razy dziennie $0,125 \mathrm{mg}$. Po inhalacji dziewczynka miała wykonywane pędzlowanie jamy ustnej z użyciem Nystatyny w zawiesinie.

W 3-7 dobie życia, w oparciu o wyniki badań laboratoryjnych (gazometrii i glikemii) zaobserwowano u dziecka zaburzenia metaboliczne: kwasice oraz hiperglikemię. Zmodyfikowano żywienie pozajelitowe oraz wypełniono łożysko pozajelitowe. Nie stosowano katecholamin i insulinoterapii.

Równolegle prowadzono leczenie farmakologiczne, obejmujące podaż: $1 \mathrm{mg}$ Midanium (sedacja przed intubacją), $10 \mathrm{mg}$ Gardenalu (leku przeciwdrgawkowy), Spironolu 1 raz dziennie $1 \mathrm{mg}$ (lek moczopędny z uwagi na okresowy wzrost poziomu sodu we krwi).

Rodzice od chwili narodzin utrzymywali kontakt z dzieckiem. Zachęcani byli przez personel oddziału do dotykania i delikatnego głaskania dziecka, z czego w pełni korzystali. Matka systematycznie odciągała pokarm, który był podawany dziecku. Rodzice w miarę możliwości przebywali z dzieckiem, włączali się w opiekę nad nim, czynnie uczestniczyli w czynnościach pielęgnacyjnych wykonywanych przy ich córce. Dziewczynka była również niejednokrotnie kangurowana, zarówno przez matkę, jak i przez ojca. Emocje, które towarzyszyły rodzicom podczas pobytu ich dziecka na oddziale, to głównie obawa, strach i lęk o stan zdrowia córki.

\section{Plan opieki pielęgniarskiej z zastosowaniem Międzynarodowej Klasyfikacji Praktyki Pielęgniarskiej (ICNP)}

Diagnoza pielęgniarska nr 1: duszność [10029433] + termin z osi Klient: noworodek [10013187]

Przedmiot: duszność [10006461] - zaburzony proces układu oddechowego: utrudnione wdychanie i wydychanie powietrza z płuc, problemy z oddychaniem, związane z niedostateczną ilością tlenu w krwioobiegu, uczucie dyskomfortu i niepokoju

\section{Interwencje + środki/narzędzia:}

- monitorowanie czynności życiowych [10032113] za pomocą urządzenia monitorującego [10012177] + pielęgniarka [10013333] + współdziałanie z lekarzem [10023565]

- monitorowanie saturacji krwi tlenem za pomocą pulsoksymetru [10032047] + pielęgniarka [10013333] + współdziałanie z lekarzem [10023565]

- monitorowanie statusu (wydolności) oddychania [10012196] + urządzenie monitorujące [10012177] + pielęgniarka [10013333] + współdziałanie z lekarzem [10023565]

- ocenianie statusu (wydolności) oddychania za pomocą urządzenia monitorującego [10002799] + pielęgniarka [10013333]

- ocenianie perfuzji tkanek [10030755] + pielęgniarka [10013333] + współdziałanie z lekarzem [10023565]

- tlenoterapia[10013921]+pielęgniarka[10013333] + współdziałanie z lekarzem [10023565]

- interpretowanie wyniku gazometrii krwi tętniczej [10010492] + pielęgniarka [10013333] + współdziałanie z lekarzem [10023565]

- administrowanie lekiem po interpretacji gazometrii tętniczej [10001794] + pielęgniarka [10013333] + współdziałanie z lekarzem [10023565]

- obserwowanie[10013474]+ pielęgniarka[10013333] + współdziałanie z lekarzem [10023565]

- dokumentowanie [10028156] + pielęgniarka [10013333]

Diagnoza pielęgniarska nr 2: spływanie wydzieliny do nosogardła [10021761] + termin z osi Klient: noworodek [10013187]

Przedmiot: spływanie wydzieliny do nosogardła [10021761] - zaburzony proces układu oddechowego

\section{Interwencje + środki/narzędzia:}

- odsysanie dróg oddechowych [10044890] + pielęgniarka [10013333]

- $\quad$ tagodzenie [10002171] + oznaka dyskomfortu [10037282] + pielęgniarka [10013333]

- obserwowanie [10013474] + wydzielina [10017635] + pielęgniarka [10013333] + współdziałanie z lekarzem [10023565]

- zmienianie [10002185] + pozycja ciała [10003433] + pielęgniarka [10013333]

- dokumentowanie [10028156] + pielęgniarka [10013333] 
Diagnoza pielęgniarska nr 3: zaburzony stan błony śluzowej jamy ustnej [10026967] + termin z osi Klient: noworodek [10013187]

Przedmiot: sucha błona śluzowa [10006351] - zaburzona funkcja błony śluzowej: małe nawilżenie, suchość, brak wydzielania, z ryzykiem tarcia i pękania, zwłaszcza w przypadku wyściółki

Interwencje + środki/narzędzia:

- obserwowanie [10013474] + błona śluzowa [10012288] + pielęgniarka [10013333]

- $\quad$ pielęgnacja jamy ustnej [10032184] + zastosowanie technik aseptycznych [10041784] + pielęgniarka [10013333]

- pielęgnacja miejsca wprowadzenia urządzeń inwazyjnych [10031592] + zastosowanie technik aseptycznych [10041784] + pielęgniarka [10013333]

- administrowanie lekiem [10025444] + profilaktyka [10015838] + pielęgniarka [10013333] + współdziałanie z lekarzem [10023565]

- monitorowanie odpowiedzi na leczenie [10032109] + pielęgniarka [10013333] + współdziałanie z lekarzem [10023565]

- $\quad$ ewaluacja odpowiedzi na lek [10007182] + pielęgniarka [10013333] + współdziałanie z lekarzem [10023565]

- dokumentowanie [10028156] + pielęgniarka [10013333]

Diagnoza pielęgniarska nr 4: efektywne odstawienie wspomagania oddechu [10028141] + termin z osi Klient: noworodek [10013187]

Przedmiot: odpowiedź na odzwyczajanie od aparatury sztucznie podtrzymującej oddychanie [10017089] odpowiedź na leczenie

\section{Interwencje + środki/narzędzia:}

- ocenianie [10002673] statusu oddychania [10016962] + urządzenie monitorujące [10012177] + pielęgniarka [10013333] + współdziałanie z lekarzem [10023565]

- monitorowanie statusu (wydolności) oddychania [10012196] + urządzenie monitorujące [10012177] + pielęgniarka [10013333] + współdziałanie z lekarzem [10023565]

- monitorowanie saturacji krwi tlenem za pomocą pulsoksymetru [10032047] + pielęgniarka [10013333] + współdziałanie z lekarzem [10023565]

- obserwowanie [10013474] powłok ciała [10010428] + pielęgniarka [10013333] + współdziałanie z lekarzem [10023565]

- interpretowanie wyniku gazometrii krwi tętniczej [10010503] + pielęgniarka [10013333] + współdziałanie z lekarzem [10023565]
- $\quad$ administrowanie lekiem po interpretacji wyniku gazometrii tętniczej [10001794] + pielęgniarka [10013333] + współdziałanie z lekarzem [10023565]

- dokumentowanie [10006173] + pielęgniarka [10013333]

Diagnoza pielęgniarska nr 5: ryzyko niewystarczającego przyjmowania pokarmów [10023021] + termin z osi Klient: noworodek [10013187]

Przedmiot: przyjmowanie pokarmów [10008101] - odżywianie: proces przyjmowania środków odżywczych, obejmujących białka, minerały, węglowodany, tłuszcze i witaminy, koniecznych do wzrastania, normalnego funkcjonowania i zachowywania życia

\section{Interwencje + środki/narzędzia}

- nauczanie o wzorcu przyjmowania pokarmu [10032918] + materiał instruktażowy [10010395] + materiał do czytania [10016433] + pielęgniarka [10013333] + termin z osi Klient: rodzic [10014023]/opiekun [10003958]

- karmienie [10007786] + technika karmienia [10007819] + pielęgniarka [10013333] + termin z osi Klient: rodzic [10014023]/opiekun [10003958]

- zarządzanie reżimem diety [10023861] + pielęgniarka [10013333] + termin z osi Klient: rodzic [10014023]/opiekun [10003958]

- ważenie pacjenta [10033323] + urządzenie do oceny [10002734] + pielęgniarka [10013333]

- pomiar wzrostu [10037000] + urządzenie do oceny [10002734] + pielęgniarka [10013333]

- ocenianie statusu odżywienia [10030660] + pielęgniarka [10013333] + współdziałanie z lekarzem [10023565]

- monitorowanie wyników laboratoryjnych [10032099] + pielęgniarka [10013333] + współdziałanie z lekarzem [10023565]

- monitorowanie odżywiania [10036032] + pielęgniarka [10013333] + współdziałanie z lekarzem [10023565]

- weryfikowanie [10020727] przyjmowania pokarmów [10008101] + pielęgniarka [10013333] + współdziałanie z lekarzem [10023565]

- ewaluacja statusu przewodu pokarmowego [10034007] + pielęgniarka [10013333] + współdziałanie z lekarzem [10023565]

- zmienianie [10002185] + reżim diety [10005951] + urządzenie do karmienia [10007803] + pokarm [10008089] + pielęgniarka [10013333] + współdziałanie z lekarzem [10023565]

- obserwowanie [10013474] efektywnej masy ciała [10027385] + pielęgniarka [10013333] + współdziałanie z lekarzem [10023565] 
- dokumentowanie [10006173] + pielęgniarka [10013333]

Diagnoza pielęgniarska nr 6: niedowaga [10027316] + termin z osi Klient: noworodek [10013187]

Przedmiot: niedowaga [10020263] - zaburzona masa ciała

Interwencje + środki/narzędzia:

- zarządzanie reżimem diety [10023861] + pielęgniarka [10013333] + termin z osi Klient: rodzic [10014023]/opiekun [10003958]

- ważenie pacjenta [10033323] + urządzenie do oceny [10002734] + pielęgniarka [10013333]

- ocenianie statusu odżywienia [10030660] + pielęgniarka [10013333] + współdziałanie z lekarzem [10023565]

- monitorowanie masy ciała [10032121] + urządzenie do oceny [10002734] + pielęgniarka [10013333] + współdziałanie z lekarzem [10023565]

- karmienie [10007786] + technika karmienia [10007819] + pielęgniarka [10013333] + termin z osi Klient: rodzic [10014023]/opiekun [10003958]

- dokumentowanie [10006173] + pielęgniarka [10013333]

Diagnoza pielęgniarska $\mathrm{nr}$ 7: ryzyko komplikacji związanych z opieką zdrowotną [10041296] + termin z osi Klient: noworodek [10013187]

Przedmiot: komplikacja związana ze świadczeniami zdrowotnymi [10041277] - komplikacja

\section{Interwencje + środki/narzędzia:}

- zarządzanie bezpieczeństwem środowiska [10042507] + pielęgniarka [10013333] + zespół wielospecjalistyczny [10039400]

- ocenianie podatności na infekcje [10002821] + pielęgniarka [10013333] + współdziałanie z lekarzem [10023565]

- monitorowanie objawów przedmiotowych i objawów podmiotowych infekcji [10012203] + pielęgniarka [10013333] + współdziałanie z lekarzem [10023565]

- prewencja przed kontaminacją [10005055] + pielęgniarka [10013333] + zespół wielospecjalistyczny [10039400] + rodzic [10014023]/opiekun [10003958]

- dezynfekowanie [10006044] + kończyna górna [10008661] + pielęgniarka [10013333] + zespół wielospecjalistyczny [10039400] + rodzic [10014023]/opiekun [10003958]

- sprawdzanie bezpieczeństwa urządzenia [10030924] + pielęgniarka [10013333] + zespół wielospecjalistyczny [10039400]
- nauczanie o środkach bezpieczeństwa $[10024687]+$ pielęgniarka [10013333] + zespół wielospecjalistyczny [10039400] + rodzic [10014023]/opiekun [10003958]

- nauczanie o urządzeniu [10032902] + pielęgniarka [10013333] + zespół wielospecjalistyczny [10039400] + rodzic [10014023]/opiekun [10003958]

- instruowanie [10010376] + pielęgniarka [10013333] + rodzic [10014023]/opiekun [10003958]

- ciągły nadzór [10005093] komplikacji [10025459] + pielęgniarka [10013333] + współdziałanie z lekarzem [10023565]

- raportowanie (sprawozdawanie) [10016771] + pielęgniarka [10013333] + zespół wielospecjalistyczny

Diagnoza pielęgniarska $\mathrm{nr}$ 8: zaburzone radzenie sobie rodziny [10034789] + termin z osi Klient: rodzic [10014023]/opiekun [10003958]

Przedmiot: radzenie sobie rodziny [10034736] - radzenie sobie

\section{Interwencje + środki/narzędzia:}

- zapewnienie materiału instruktażowego [10024493] + materiał instruktażowy [10010395] + materiał do czytania [10016433] + pielęgniarka [10013333] + współdziałanie z lekarzem [10023565]

- zapewnieniewsparciaemocjonalnego[10027051] + pielęgniarka [10013333] + współdziałanie z lekarzem [10023565]

- promowanie efektywnego sprawowania opieki rodzicielskiej [10032496] + pielęgniarka [10013333] + zespół wielospecjalistyczny [10039400]

- nauczanie o efektywnym rodzicielstwie [10032994] + pielęgniarka [10013333] + zespół wielospecjalistyczny [10039400]

- doglądanie [10002911] + pielęgniarka [10013333]

- pielęgniarka [10013333] + zespół wielospecjalistyczny [10039400]

- nauczanie o opiece nad niemowlęciem [10037118] + materiał instruktażowy [10010395] + materiał do czytania [10016433] + pielęgniarka [10013333]

- nauczanie o efektywnej masie ciała [10033001] + materiał instruktażowy [10010395] + materiał do czytania [10016433] + pielęgniarka [10013333]

- nauczanie o karmieniu niemowlęcia [10037139] + materiał instruktażowy [10010395] + materiał do czytania [10016433] + pielęgniarka [10013333] 
- nauczanie o bezpieczeństwie dziecka [10037160] + pielęgniarka [10013333] + współdziałanie z lekarzem [10023565]

- nauczanie rodziny o reżimie terapii [10024656] + materiał instruktażowy [10010395] + materiał do czytania [10016433] + pielęgniarka [10013333] + współdziałanie z lekarzem [10023565]

- wspieranie procesu radzenia sobie rodziny [10032859] + pielęgniarka [10013333] + zespół wielospecjalistyczny [10039400]

- $\quad$ zwiększanie pewności siebie [10006796] + pielęgniarka [10013333] + zespół wielospecjalistyczny [10039400]

- poradnictwo dotyczące nadziei [10026212] + zespół wielospecjalistyczny [10039400]

- $\quad$ poradnictwo dotyczące strachu [10026208] + zespół wielospecjalistyczny [10039400]

- chwalenie [10015409] + pielęgniarka [10013333] + zespół wielospecjalistyczny [10039400]

- pocieszanie[10004664]+ pielęgniarka[10013333] + zespół wielospecjalistyczny [10039400]

\section{Dyskusja}

Wcześniak jest niezwykle wymagającym pacjentem w zakresie pielęgnacji, a jej jakość ma decydujące znaczenie dla dalszych rokowań. Im mniejszy i młodszy wiek, tym częściej występuje bezpośrednie zagrożenie życia i tym większa umieralność [1, 2]. Ze względu na specyfikę tej populacji noworodków pielęgniarki/położne sprawujące nad nimi opiekę powinny znać występujące u nich odrębności fizjologiczne oraz czynniki utrudniające wcześniakom adaptację do życia pozałonowego.

Poród przedwczesny, poród przez cięcie cesarskie, ciąża mnoga, cukrzyca u matki, płeć męska, zamartwica, hipotermia, rasa biała to czynniki, które England uważa za predysponujące do wystąpienia u noworodka ZZO [14]. W analizowanym przypadku czynnikami ryzyka rozwoju ZZO były: poród przedwczesny oraz cięcie cesarskie.

Bielenik wskazuje, iż następstwem wcześniactwa może być m.in.: dysplazja oskrzelowo-płucna, retinopatia wcześniacza, zaburzenia słuchu, martwicze zapalenie jelit, wylewy około- i dokomorowe, padaczka, mózgowe porażenie dziecięce, wady rozwojowe [5]. Także u noworodka, którego sytuację chorobową poddano analizie w niniejszej pracy, wystąpiły: dysplazja oskrzelowo-płucna, retinopatia wcześniacza, wylewy okołoi dokomorowe.

Jak podaje Behrendt, nawracające bezdechy, hipowentylacja, niewydolność krążenia pochodzenia sercowego, wzmożony wysiłek oddechowy, hiperkapnia i hipoksemia są głównymi wskazaniami do zastosowania tlenoterapii metodą inwazyjną [8]. Wskazaniem do zastosowania wentylacji prowadzonej metodą przerywanej wentylacji obowiązkowej (IMV) w przedstawionym w pracy studium przypadku były: nawracające bezdechy, hipowentylacja oraz wzmożony wysiłek oddechowy.

Manowska wskazuje, iż wentylacja prowadzona metodą inwazyjną zapewnia odpowiednią oksygenację tkanek oraz usunięcie dwutlenku węgla [15]. Bober-Olesińska i Borszewska-Kornacka zalecają, aby wentylacja mechaniczna była stosowana jak najkrócej i zastępowana była metodami nieinwazyjnymi ze względu na powikłania, jakie za sobą niesie, czyli dysplazję oskrzelowo-płucną oraz uszkodzenie miąższu płuc [11]. Niestety dysplazja oskrzelowo-płucna, jako powikłanie wentylacji mechanicznej, pomimo szybkiej zamiany tej metody na nieinwazyjne wspomaganie oddychania prowadzone w systemie IMV, wystąpiły także u wcześniaka, którego historię chorobową przedstawiono w niniejszej pracy.

Pielęgniarki odgrywają bardzo ważną rolę w zespole terapeutycznym. Koncentrując się na delikatnym wykonywaniu czynności diagnostycznych, terapeutycznych oraz pielęgnacyjnych dostosowanych do indywidualnych potrzeb pacjenta zgodnie z przyjętymi procedurami oraz zachowaniem zasad aseptyki i antyseptyki, przyczyniają się do skrócenia czasu hospitalizacji oraz poprawy stanu ogólnego pacjenta. W swojej pracy posługują się zindywidualizowanym procesem opieki, który stanowi podstawę do planowania i dokumentowania sprawowanej opieki. Służy temu m.in. klasyfikacja ICNP, która została zaprezentowana w niniejszym opracowaniu. Opiera się na terminologii referencyjnej, której głównym zadaniem jest uporządkowanie i ujednolicenie praktyki pielęgniarskiej, pozwala na powszechne rozumienie diagnoz i interwencji pielęgniarskich poprzez posługiwanie się przypisanymi im kodami. Stanowi ona wsparcie dla pracy pielęgniarskiej z wykorzystaniem procesu pielęgnowania [16, 17].

Stosowanie klasyfikacji ICNP przynosi także korzyści dla samego pielęgniarstwa i pracy, jaką wykonuje personel pielęgniarski. Jej zakładana spójność z innymi systemami klasyfikacyjnymi, stosowanymi do dokumentowania opieki nad pacjentem przez pozostałych członków zespołu terapeutycznego, pozwala na uwidocznienie pracy pielęgniarek, a przede wszystkim jej znaczenia dla procesu terapeutycznego. Dzięki tej klasyfikacji możliwe jest gromadzenie danych o tzw. wrażliwych wskaźnikach opieki pielęgniarskiej, które mogą i są wykorzystywane do oceny jakości tej formy opieki i jej wpływu na wyniki leczenia [17]. Dokumentowanie elektroniczne pozwala nie tylko na zbieranie informacji o przebiegu leczenia, ale także na swobodne jej przetwarzanie i odtwarzanie w sytuacji, gdy pacjent leczony jest w innym miejscu, przez inny zespół terapeutyczny. 


\section{Piśmiennictwo}

1. Borszewska-Kornacka KM. Kompendium wiedzy o wcześniaku. Stand Med 2013;10(5): 597-608.

2. Chrzan-Dętkoś M. Wcześniaki. Rozwój psychoruchowy w pierwszych latach życia. Gdańsk: Harmonia Universalis; 2012. 17-23.

3. Bałanda A, Skurzak A, Iwanowicz-Palus G. Zadania pielęgniarki i położnej w opiece nad noworodkiem w zakresie wspomagania oddychania za pomocą Infant Flow. Piel XXI w 2006; 4(17):133-131.

4. Wechsler Linden D, TrentiParoli E, Wechsler D. Wcześniak. Pierwsze 6 lat życia. Warszawa: PZWL; 2007. 38-40.

5. Bielenik $Ł$. Dzieci urodzone przedwcześnie w percepcji matek. Gdańsk: Harmonia Universalis; 2012. 3-10.

6. Rozalska-Walaszek I, Lesiuk W, Aftyka A, Kandzierski G. Udział pielęgniarki w opiece nad noworodkiem wymagającym wsparcia oddechowego. Piel XXI w 2013; 3(44): 51-55.

7. Bałanda A (red.). Opieka nad noworodkiem. Warszawa: PZWL; 2009. 25.

8. Behrendt J, Bursa. Ostra niewydolność oddechowa. W: Godula-Stuglik U (red.). Wybrane zagadnienia z patologii noworodka. Katowice: Śląska Akademia Medyczna; 2003. 16-19.

9. Pokrzywnicka M, Kwiatkowska M, Oziemska M, Krajewski P. Ocena porównawcza zastosowania poractantu alfa w dwóch dawkach u wcześniaków z zespołem zaburzeń oddychania. Post Neonatol 2006; 2(10): 27-31.

10. Krajewski P, Chudzik A, Górska M, Strzałko-Głoskowska B, Kmiecik M, Mesjasz A et.al. Czy dotchawicze podanie surfaktantu bez konieczności intubacji i stosowania wentylacji mechanicznej jest szansą dla noworodków przedwcześnie urodzonych. Post Neonatol 2014; 2(20): 26-30.

11. Bober-Olesińska K, Borszewska-Kornecka MK. Europejskie wytyczne leczenia zespołu zaburzeń oddychania - aktualne rekomendacje. Stand Med 2014;4(11): 485-487.

12. Lesińska-Sawiecka M (red.). Metoda case study w pielęgniarstwie. Wybrane zagadnienia. Warszawa: Wydawnictwo Medyczne Borgis; 2009. 38-51
13. Lenartowicz H, Kózka M. Metodologia badań w pielęgniarstwie. Podręcznik dla studiów medycznych. Warszawa: PZWL; 2010. 97-109.

14. England C. Zaburzenia oddechowe u noworodka. W: Lumsden H, Holmes D, Iwanowicz-Palus GJ, [red]: Noworodek i jego rodzina. Praktyka położnicza. Warszawa: PZWL; 2012. 159-167.

15. Manowska M. Postępowanie w stanach zagrożenia życia u dzieci. W: Kawalec W, Grenda R, Ziółkowska H. Pediatria. T.2. Warszawa: PZWL; 2013. 1187-1189.

16. Kilańska D, Staszewska M, Urbanek N, Andrzejczak A, Purgał J. Planowanie opieki według międzynarodowego standardu ICNP $^{\circledR}$ w Podstawowej Opiece Zdrowotnej - studium przypadku. Probl Piel 2014, tom 22, zeszyt nr 4: 539-545.

17. Kilańska D (red. naukowa). Międzynarodowa Klasyfikacja Praktyki Pielęgniarskiej, ICNP ${ }^{\circledR}$ w praktyce pielęgniarskiej. Warszawa: PZWL; 2014. 49-59.

Artykuł przyjęty do redakcji: 05.08.2016

Artykuł przyjęty do publikacji: 30.08.2016

Źródło finansowania: Praca nie jest finansowana z żadnego źródła. Konflikt interesów: Autorzy deklarują brak konfliktu interesów.

Adres do korespondencji:

Lucyna Sochocka

ul. Katowicka 68

45-060 Opole

tel.: 660207056

e-mail: I-sochocka@wp.pl

Instytut Pielęgniarstwa,

Państwowa Medyczna Wyższa Szkoła Zawodowa w Opolu 